alsinfint
JURNAL PENELITIAN BAHASA, SASTRA, DAN

BUDAYA ARAB

P-ISSN: 2615-7241 | E-ISSN: 2721-480X // Vol. 2 No. 1 | 40-57

(1) https://ejournal.upi.edu/index.php/alsuniyat/index

\title{
ANALISIS KONTRASTIF KALIMAT SYARAT BAHASA ARAB DAN BAHASA INDONESIA
}

\author{
Vini Qonita Qistifani \\ SMP Terpadu Baiturrahman Ciparay Bandung, Indonesia \\ E-mail: viniqonita@gmail.com
}

\begin{abstract}
:
This study aims to determine the sentence structure of Arabic and Indonesian terms in Surah Al-Baqarah, their similarities and differences, and their implications for translation. The research method used in this study is a descriptive method with a qualitative approach. Data collection techniques used were documentation and triangulation studies. From the results of this study, researchers found 190 the number of shar'iyah in surah AlBaqarah with various sentence structures. Then, some similarities and differences in the structure between the sentence terms in Arabic and Indonesian, as well as the implications of this study, the researcher found a tendency to translate adawat syart on the translation of the Ministry of Religion and Al-Mishbah.
\end{abstract}

\section{Keywords:}

Contrastive; Sentence Terms; Translation

\begin{abstract}
Abstrak
Penelitian ini bertujuan untuk mengetahui struktur kalimat syarat bahasa Arab dan bahasa Indonesia dalam surah Al-Baqarah, persamaan dan perbedaannya, serta implikasinya terhadap penerjemahan. Metode penelitian yang digunakan dalam penelitian ini adalah metode deskriptif dengan pendekatan kualitatif. Teknik pengumpulan data yang digunakan adalah studi dokumentasi dan triangulasi. Dari hasil penelitian ini, peneliti menemukan 190 jumlah syarțiyah dalam surah Al-Baqarah dengan struktur kalimat yang beragam. Kemudian, beberapa persamaan dan perbedaan pada struktur antara kalimat syarat bahasa Arab dan bahasa Indonesia, serta implikasi dari penelitian ini, peneliti menemukan kecenderungan penerjemahan adawat syart pada terjemah Depag maupun Al-Mishbah.

Kata Kunci:

Kontrastif; Kalimat Syarat; Penerjemahan
\end{abstract}

\section{PENDAHULUAN}

Bahasa Indonesia sebagai bahasa pertama (B1) yang digunakan para pelajar di Indonesia, mempunyai persamaan dan perbedaan tersendiri dengan bahasa Arab sebagai bahasa target dan bahasa yang dipelajari (B2). Persamaan dalam B1 dan B2 akan memberikan keringanan kepada pelajar dalam memahami bahasa asing. Dengan adanya persamaan antara B1 dan B2, pelajar tidak mesti mempelajari dua materi berbeda.

Perbedaan pada kedua bahasa tersebut sangat beragam, di antaranya bisa dilihat dari segi fonetik, sintaksis, maupun morfologisnya. Perbedaan ini menjadi salah satu kendala yang dialami oleh pembelajar bahasa asing. Kendala tersebut terkadang membuat pelajar merasa bahwa pembelajaran bahasa asing sulit, sehingga pelajar kurang menyukai pembelajaran bahasa asing. 
Salah satu cara yang dapat meringankan pembelajar dalam mempelajari bahasa asing tadalah dengan adanya komparasi atau perbandingan pada kedua bahasa. Dengan diadakannya perbandingan antara dua bahasa tersebut, pembelajar dapat mengetahui persamaan dan perbedaannya. Di dalam analisis kontrastif terdapat dua bahasa, kemudian perbedaan struktur kedua bahasa tersebut diidentifikasi, lalu unsur-unsur yang berbeda dipelajari kemungkinannya sebagai penyebab kesukaran dalam pembelajaran bahasa asing yang dipelajari (Ahmadi, 2014:125).

Kalimat adalah salah satu bagian yang dipelajari dalam sebuah bahasa. Harimurti (2001:22) menyebutkan bahwa manusia mengungkapkan isi hati, pikiran, dan perasaannya dengan suatu alat yang dinamakan bahasa melalui proses pengujaran. Hasil pengujaran disebut ujar, yaitu kalimat atau bagian kalimat yang dilisankan.

Setiap bahasa mempunyai struktur kalimat berbeda-beda dan mempunyai ciri khasnya masing-masing. Bahasa yang baik dan komunikatif tersusun dari kalimat yang baik pula. Kalimat yang tersusun sesuai dengan struktur bahasa yang baik akan memudahkan pendengar dalam memahami apa yang dibicarakan oleh penutur.

Dalam berbahasa, seseorang dituntut untuk mampu membentuk kalimat yang benar, sehingga perkataannya dapat dipahami oleh orang lain. Hal ini sepadan dengan pendapat Chaer (2007) bahwa kalimat merupakan sesuatu yang langsung digunakan dalam berbahasa, para tata bahasawan tradisional mengaitkan definisi kalimat dengan peranannya, yaitu sebagai alat interaksi dan kelengkapan pesan atau isi yang disampaikan.

Dalam bahasa Arab, kalimat syarat ditandai dengan adanya adat Syarț, sedangkan dalam bahasa indonesia ditandai dengan adanya konjungsi yang menyatakan syarat. adat Syart yang ada dalam bahasa Arab sangat beragam dan memiliki fungsi-fungsi tersendiri. Walaupun beberapa adat Syarț mempunyai arti yang hampir sama dalam bahasa Indonesia, tetapi memiliki fungsi sintaksis yang berbeda dalam bahasa Arab. Sehingga terkadang pelajar keliru dalam membuat atau menerjemahkan bentuk kalimat syarat.

Dalam kalimat syarat pada Bahasa Arab, setiap adat Syarț akan mempengaruhi bentuk dan makna kata yang digunakan. Seperti penggunaan harf 'إن’ dalam sebuah kalimat, akan menjazmkan dua fi'il, sedangkan penggunaan harf ' menjazmkan dua fi'il. Adapun dalam bahasa Indonesia konjungsi yang menyatakan syarat, bisa menggantikan peran satu sama lain. Chaer (2007)menjelaskan bahwa kalimat dengan konjungsi 'kalau' pada awal klausa bawahan, perannya dapat digantikan oleh konjungsi 'jika', 
konjungsi 'jika' dapat digantikan perannya oleh konjungsi 'jikalau', kemudian, konjungsi 'bila' juga dapat menggantikan peran 'kalau'.

Selanjutnya, Al Farisi (2014:23) mendefinisikan terjemah sebagai upaya mengalihkan amanat dari bahasa sumber ke dalam bahasa target dengan cara menemukan ekuivalensi yang memiliki struktur semantik sepadan dan membangun mabna dan makna sesuai.

Di zaman sekarang ini penerjemahan sangat dibutuhkan guna memahami ilmu-ilmu lain yang termaktub dalam bahasa yang asing bagi kita. Ini dapat kita lihat dengan makin banyaknya hasil penelitian yang telah dilakukan oleh para peneliti luar negeri yang tentunya menggunakan bahasa peneliti itu sendiri atau bahasa internasional. Kemudian, kesulitan yang juga di alami dalam pembelajaran bahasa Arab salah satunya adalah penerjemahan. Pengalihbahasaan dari bahasa Arab ke dalam bahasa Indonesia ataupun sebaliknya menjadi hal yang agak sulit untuk pelajar. Karena penerjemahan menuntut untuk tersampaikannya amanat dari bahasa sumber ke dalam bahasa target sehingga penerjemah harus benar-benar memahami teks bahasa sumber yang akan diterjemahkan ke dalam bahasa target. Kesalahan dalam penerjemahan akan berdampak pada isi/kandungan dari bahasa asing tersebut.

Dengan demikian, fokus penelitian ini adalah mengkomparasikan antara kalimat syarat dalam bahasa Arab dan bahasa Indonesia pada surah Al-Baqarah beserta terjemahnya serta bagaimana implikasinya terhadap penerjemahan setelah mengetahui persamaan dan perbedaan pada kedua bahasa tersebut.

\section{METODE}

Metode yang digunakan dalam penelitian ini adalah metode deskriptif dengan pendekatan kualitatif. Desain penelitian yang akan dilakukan pada penelitian ini adalah analisis konten (isi). Peneliti akan mengumpulkan dan menganalisis konten dari sebuah teks. Data yang akan dianalisis pada penelitian ini adalah kalimat syarat bahasa Arab dan bahasa Indonesia pada surah Al-Baqarah beserta terjemahnya. Data yang telah peneliti temukan akan dianalisis untuk diketahui persamaan dan perbedaannya dari segi sintaksis. Kemudian setelah diketahui persamaan dan perbedaanya, disimpulkan bagaimana implikasinya terhadap penerjemahan.

Dalam menentukan objek penelitian, peneliti harus menentukan sampel yang representatif sehingga dapat menghasilkan informasi yang lengkap serta akurat. Teknik pengambilan sampel yang digunakan dalam penelitian ini adalah teknik purpossive sampling, yaitu pengambilan sampel dengan beberapa pertimbangan tertentu. Peneliti mengambil surah Al-Baqarah sebagai sampel dalam penelitian ini. Pengambilan surah Al-Baqarah sebagai sampel 
dikarenakan surah Al-Baqarah adalah surah terpanjang dalam Al-Qur'an, sehingga probabilitas jenis dan variasi kalimatnya lebih banyak dibanding surah lain.

\section{HASIL DAN PEMBAHASAN}

\section{Struktur Kalimat Syarat Bahasa Arab dan Bahasa Indonesia pada Surah Al-Baqarah}

1. Jumlah syarțiyah berdasarkan jenis dan fungsi adat syarț-nya

Pada surah Al-Baqarah, terdapat berbagai macam adawat syarț. Berdasarkan jenisnya, adat syarț terbagi menjadi isim dan harf. Sedangkan berdasarkan fungsi adat syart terbagi menjadi jazim dan ghair jazim. adat syarț jazim berfungsi untuk men-jazm-kan kedua fi'il dalam jumlah syarțiyah yakni fi'il syarț dan jawab syarț.

إن - مَن - ما - مهما - منى - أيَّان - أين - أينما

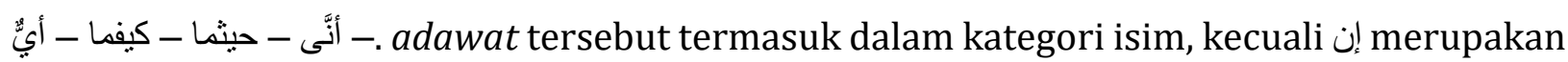
harf (Suhendar 2014), Bihauddin, 1987).

Seperti Jumlah syarțiyah yang terdapat pada ayat 23 adalah Jumlah syarțiyah dengan adat syarț berjenis harf

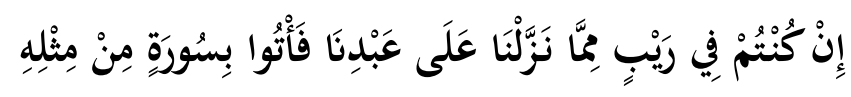

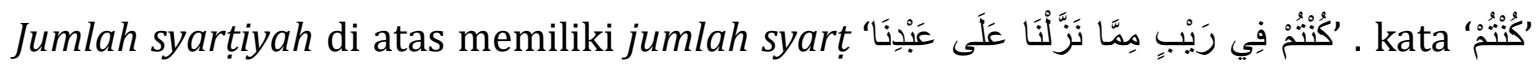

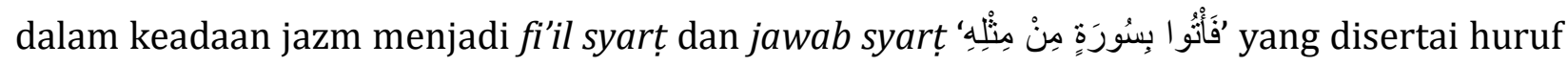
fa (ف) karena jawab syarț berupa jumlah țalbiyah dengan bentuk fi'il amr.

Adapun terjemah dari jumlah syarțiyah di atas Jika kamu meragukan (Al-Qur'an) yang kami turunkan kepada hamba kami (Muhammad), maka buatlah satu surah semisal dengannya.

Kalimat Jika kamu meragukan (Al-Qur'an) yang kami turunkan kepada hamba kami (Muhammad), sebagai protasis di mana kalimat tersebut menyatakan keterangan syarat, hal ini ditandai dengan adanya konjungsi yang menyatakan syarat yaitu jika. Kemudian, kalimat maka buatlah satu surah semisal dengannya sebagai apodosis di mana kalimat tersebut menyatakan akibat dari kalimat syarat sebelumnya. Kemudian, kalimat protasis mempunyai peran sebagai anak kalimat (Aka).

Menurut Putrayasa (2010), anak kalimat (Aka) keterangan berfungsi menerangkan predikat. Hubungan anak kalimat keterangan dengan induk kalimat dapat dibedakan menjadi dua macam, pertama hubungan eksplisit (hubungan tersebut ditandai dengan digunakannya kata penghubung) dan kedua hubungan implisit (hubungan tersebut tidak 
ditandai dengan kata penghubung). Kalimat tersebut disebut sebagai aka karena ditandai dengan adanya konjungi yang menyatakan syarat yaitu jika.

Adapun pada terjemah Al-Mishbah, Jika kamu (tetap) dalam keraguan tentang apa yang Kami turunkan kepada hamba Kami (Muhammad), maka buatlah satu surat (saja) yang semisal dengannya.

Kalimat Jika kamu (tetap) dalam keraguan tentang apa yang Kami turunkan kepada hamba Kami (Muhammad), sebagai protasis di mana kalimat tersebut menyatakan keterangan syarat, hal ini ditandai dengan adanya konjungsi yang menyatakan syarat yaitu jika. Kemudian, kalimat maka buatlah satu surat (saja) yang semisal dengannya sebagai apodosis di mana kalimat tersebut menyatakan akibat dari kalimat syarat sebelumnya. Protasis sebagai anak kalimat (Aka) yang menerangkan predikat pada induk kalimat yakni apodosis.

Kemudian pada surah Al-Baqarah ayat 108 terdapat jumlah syarțiyah dengan adat syarț berjenis isim, yakni مَن Isim sَ digunakan untuk yang berakal, dalam keadaan rafa' mempunyai fungsi sebagai mubtada', dalam keadaan nasb menjadi maf'ul bih apabila fi'il syarț muta'addi. (Bihauddin. 1987:143)

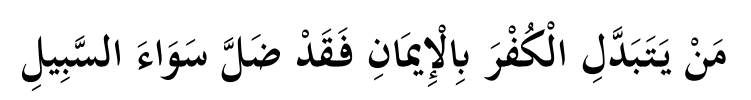

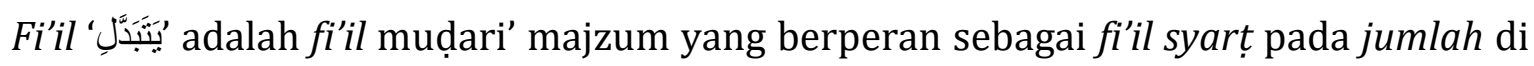

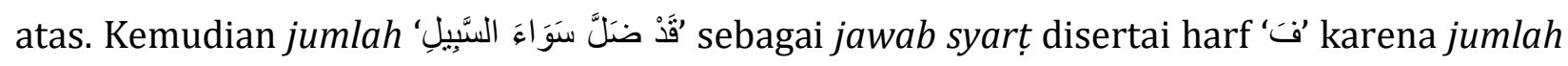

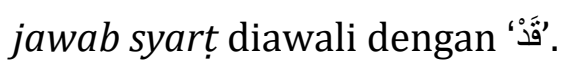

Terjemah dari jumlah di atas, Barang siapa mengganti keimanan dengan kekafiran, maka sungguh, dia telah tersesat dari jalan yang lurus. Kalimat Barang siapa mengganti keimanan dengan kekafiran sebagai anak kalimat dengan jenis kalimat tunggal, berperan sebagai protasis yang menyatakan syarat pada kalimat di atas.adapun kalimat tunggal adalah kalimat yang terdiri atas satu klausa atau satu konstituen (Kridalaksana, 2001:9). Sedangkan kalimat maka sungguh, dia telah tersesat dari jalan yang lurus sebagai induk kalimat dengan jenis kalimat tunggal dengan perluasan keterangan pada predikat 'tersesat', berperan sebagai apodosis yang menyatakan akibat dari kalimat pernyataan syarat sebelumnya.

Adapun pada terjemah Al-Mishbah, Barangsiapa yang menukar iman dengan kekafiran, maka sungguh orang itu telah sesat dari jalan tengah. Kalimat Barangsiapa yang 
menukar iman dengan kekafiran sebagai anak kalimat dengan jenis kalimat tunggal, berperan sebagai protasis yang menyatakan syarat pada kalimat di atas. adapun kalimat tunggal adalah kalimat yang terdiri atas satu klausa atau satu konstituen (Kridalaksana, 2001:94). Sedangkan kalimat maka sungguh orang itu telah sesat dari jalan tengah sebagai induk kalimat dengan jenis kalimat tunggal dengan perluasan keterangan pada predikat telah sesat, berperan sebagai apodosis yang menyatakan akibat dari kalimat pernyataan syarat sebelumnya.

Adapun Adat syart ghair jazimah adalah adat yang memasuki dua kalimat. Kalimat pertama disebut fi'il syarț dan kalimat kedua disebut jawab syarț. Adat syart ghair jazimah di antaranya إذا ، لو لا ، لوما، كلما ، أما ، لما (Bihauddin, 1987:77).

Adat كلما termasuk harf syarț yang menunjukkan pengulangan, dalam keadaan nasb menjadi maf'ul fiih. syarț dan jawabnya merupakan fi'il madhi (Bihauddin. 1987: 78). Jumlah syarțiyah pada surah Al-Baqarah ayat 103 adalah jumlah syarțiyah dengan adat syart ghair jazim berjenis harf yakni (لو):

Adat لو merupakan harf imtina' yang masuk pada fi'il madhi. Jika masuk pada isim atau mashdar muawwal maka dalam keadaan rafa' menjadi fa'il. Jawab لو berbentuk lampau secara lafadz atau makna, makna lampau, lafadz lampau dan makna yang akan datang. Jawab لو disertai dengan lam apabila mutsbat (Bihauddin, 1987:77).

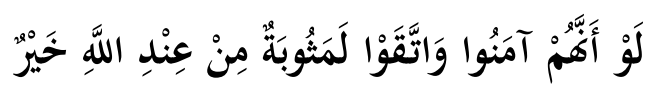

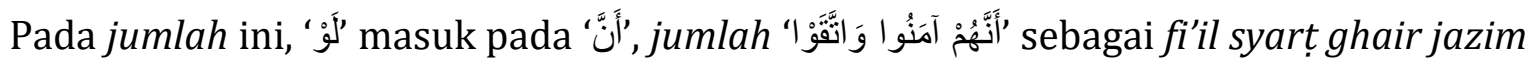

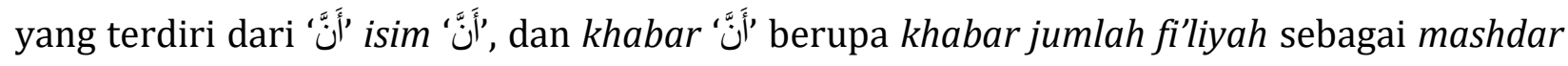

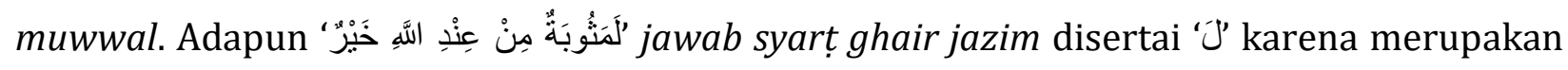
jumlah muthbat.

Terjemah jumlah di atas, Jika mereka beriman dan bertakwa, pahala dari Allah pasti lebih baik. Kalimat Jika mereka beriman dan bertakwa adalah anak kalimat syarat juga sebagai protasis yang ditandai adanya penghubung jika. Kemudian, kalimat pahala dari Allah pasti lebih baik adalah induk kalimat juga apodosis sebagai kalimat yang menyatakan akibat dari kalimat syarat sebelumnya.

Adapun terjemah Al-Mishbah dari jumlah di atas, Sesungguhnya, seandainya mereka beriman dan betakwa (niscaya mereka mendapat ganjaran). Sesungguhnya ganjaran dari sisi Allah adalah lebih baik. Kalimat Sesungguhnya, seandainya mereka beriman dan betakwa 
(niscaya mereka mendapat ganjaran). adalah anak kalimat syarat juga sebagai protasis yang ditandai adanya penghubung seandainya. Kemudian, kalimat Sesungguhnya ganjaran dari sisi Allah adalah lebih baik adalah induk kalimat juga apodosis sebagai kalimat yang menyatakan akibat dari kalimat syarat sebelumnya.

Pada surah Al-Baqarah peneliti menemukan bahwa jumlah syarțiyah dengan adat syarț selalu diikuti oleh Jyang menyertai jawab syarțya. Adapun bentuk jawab syart yang diikuti oleh $\mathrm{J}$ adalah jawab syarț dengan bentuk kalimat positif. Adapun adat syarț dengan jawab syarț bentuk kalimat negatif tidak disertai J. Seperti pada surah Al-Baqarah ayat 253:

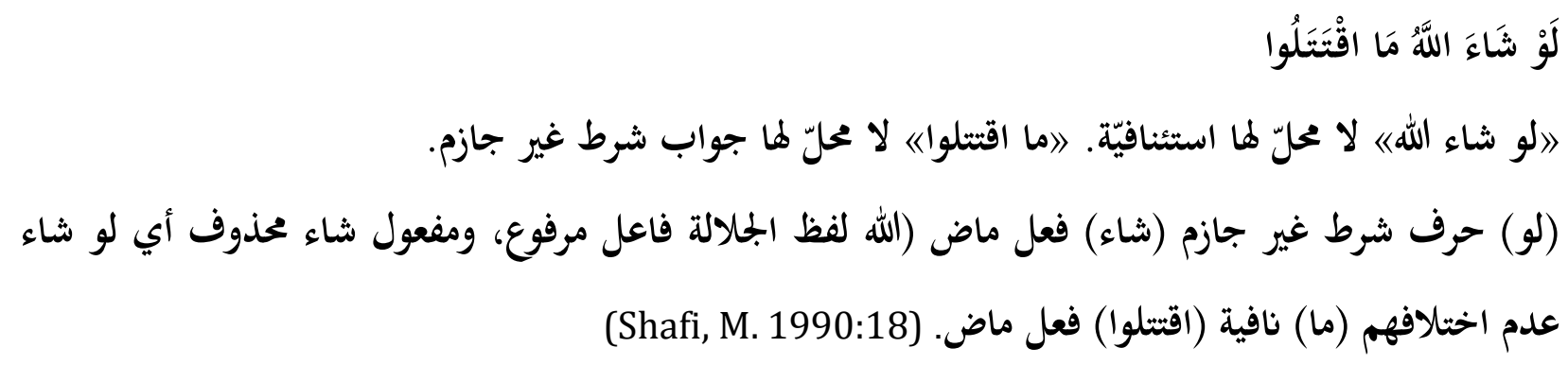

Terjemah Depag dari ayat di atas, Kalau Allah menghendaki, tidaklah mereka berbunuh-bunuhan. Terjemah dari jawab syart pada jumlah di atas adalah tidaklah mereka berbunuh-bunuhan. Pada kalimat di atas, terdapat kata tidak yang menyatakan bahwa kalimat di atas adalah kalimat negatif. Begitu pula terjemah Al-Mishbah, Seandainya Allah menghendaki, tidaklah mereka berbunuh-bunuhan. Pada terjemah Al-Mishbah pun terdapat kata negatif tidaklah.

2. Jumlah syarțiyah berdasarkan jenis jawab syarțya

Di bawah ini, peneliti akan memaparkan jumlah syarțiyah pada surah AlBaqarahberdasarkan jenis jawab syarț-nya.

Pada surah Al-Baqarah ayat 11:

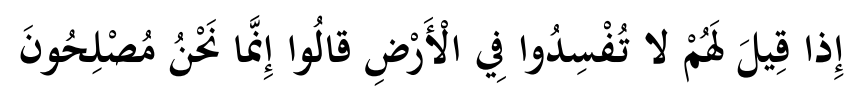

Jawab syarṭ̂ 'قالُوا إِنَّما نَحْنُ مُصنِلِحُونَ Jenis jawab syarț-nya adalah jumlah fi'liyah dengan fi'il māḍi tidak disertai harf ' $f a$ '. Hal ini senada dengan teori:

Pada dasarnya, jawab syarț tidak disertai harf 'الفاء'. Namun, jawab syarț wajib disertai harf 'الفاء' (baik yang adat syarț nya jazim ataupun ghair jazim ) jika jawab syarț:

1) Jawab syarț berupa jumlah ismiyyah (baik mabni ataupun manfi)

2) Jawab syarț berupa jumlah fi'liyah dengan fi'il jamid (yakni fi'il ghair mutasharif seperti (بئس dan 
3) Jawab syarț berupa jumlah fi'liyah yang didahului سوف ,السين ,قد ,ما ,لن dan sebagainya (Ni'mah, F, tt:178).

Pada surah Al-Baqarah ayat Al-baqarah ayat 20:

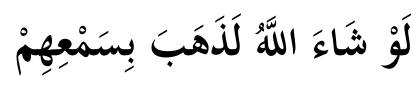

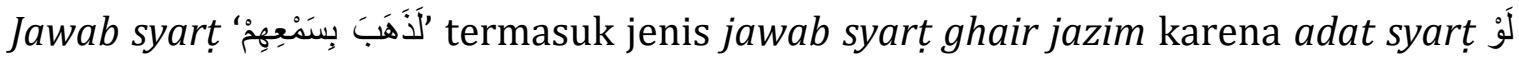
termasuk adawat syart ghair jazim. Adapun bentuk jumlahnya adalah jumlah fi'liyah dengan fi'il madhi dan disertai “ $" J$ ”.

Sedangkan pada surah Al-Baqarah ayat 23:

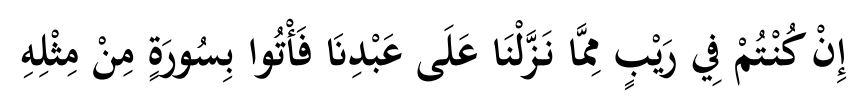

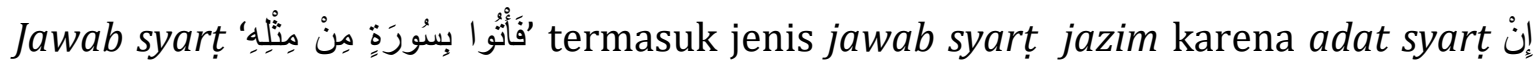
termasuk adawat syart jazim. Adapun bentuk jawab syarț-nya adalah jumlah fi'liyah disertai ḥarf 'fa' karena fi'il yang digunakan merupakan fi'il țalaby dengan fi'il amr.

Kemudian pada surah Al-Baqarah ayat 26:

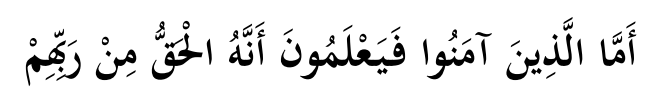

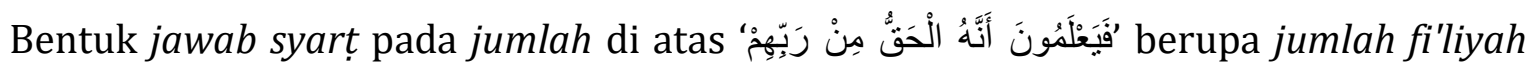
dengan fi'il mudhari' dan disertai harf 'fa'. Jawab syarț tersebut tidak dalam keadaan majzum dikarenakan adat syarṭya yaitu 'أََّ' ghair jazim.

Selanjutnya pada surah Al-Baqarah ayat 40:

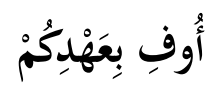

Pada jumlah syarțiyah di atas, hanya terdiri dari jawab syarț muqaddar dengan fi'il mudhari' majzum dan tidak disertai dengan harf 'فَ'. Adapun i'rab ayat di atas dalam

$$
\text { جارّ وججرور ومضاف فعل مضارع جزوم بجواب الطلب وعلامة الجزم حذف حرف العلّة، والفاعل ضمير مستتر تقديره أنا (بعهدكم) }
$$

(Shafi, M. 1990:113).

Adapun terjemahnya, Aku penuhi janji-Ku kepadamu Hanya terdiri dari satu buah kalimat sederhana. Menurut Chaer (2007), kalimat sederhana adalah kalimat yang dibentuk dari sebuah klausa yang unsur-unsurnya berupa kata atau frase sederhana.

Jika melihat pada I'rab Al-Qur'an yang ditulis oleh Mahmud șafi, jumlah di atas mempunyai makna jawab syarț dikarenakan adanya adat syarț dan fi'il syarț yang tidak 
disebutkan yaitu إن نوفو yang dapat diartikan sebagai jika kalian memenuhi/penuhi janji, yang

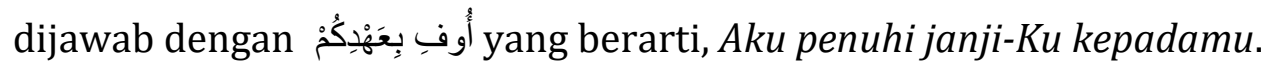

Adapun terjemah Al-Mishbah jumlah di atas. Niscaya aku penuhi janji-Ku kepada kamu. Pada kalimat tersebut terdapat kata niscaya yang dalam KBBI bisa juga diartikan sebagai tentu, pasti, tidak boleh tidak. Dapat diketahui bahwa pada terjemah Al-Mishbah lebih menekankan bahwa Allah pasti akan memenuhi janjinya bila mereka telah memenuhi janjinya kepada Allah. Sehingga kalimat di atas bisa menjadi apodosis tanpa adanya protasis yang menyatakan syarat.

3. Jumlah syarțiyah berdasarkan kelengkapan unsur-unsur yang terdapat dalam jumlah syarț. تتكون (جملة) الشرط من جزئين: الشرط و الجواب أو الجزاء، تربط بينهما كلمة شرطية ، و هذه الكلمة قد تكون حرفا و قد تكون الما. (Ar-Rajih, 2000)

Dari teori yang dikemukakan di atas, dapat diketahui bahwa unsur-unsur yang membentuk sebuah jumlah syarțiyah di antaranya adalah adat syarț baik berupa harf maupun isim, kemudian fi'il syarț atau jumlah syarț dan terakhir jawab syarț.

Pada surah Al-Baqarah, peneliti menemukan beberapa jumlah syarțiyah di mana unsur-unsur pembentuknya tidak lengkap. Seperti pada surah Al-Baqarah ayat 22:

فَلَ تَبَمَلُوا لِلَّهِ أَنْدَادًا

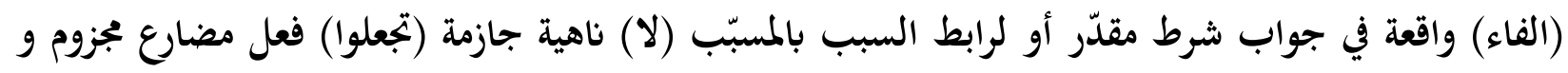
علامة جزمه حذف النون و (الواو) ضمير متصل في محل رفع فاعل (لله) جار و مجرور متعلق بمحذوف مفعول به ثان - أو هو المفعول الثاين، (أندادا)مفعول به أول منصوب.

لَا تَّمَلُوا: في محل جزم جواب شرط مقدّر أي إن كرّمكم الله بهذا الحخيرات فلا تجعلو لله أندادا، أو تعليليّة في

محل جزم جواب شرط مقدر أي إن كرّمكم الله بمذا الحخيرات فَلَا ثَبْمَلُوا لِلَّهِ أَنْدَادًا (Shafi, M. 1990:73). Jumlah syarțiyah di atas, tidak disertai dengan adat syarț dan fi'il syarț. Jumlah di atas dalam keadaan jazim ditakdirkan menjadi jawab syarț dengan fi'il țalbiyah nahyi disertai harf ' ${ }^{\prime}$ ', karena mempunyai makna syart.

Terjemah dari jumlah di atas, Karena itu, janganlah kamu mengadakan tandingantandingan bagi Allah. Adapun pada terjemah Al-Mishbah, Karena itu janganlah kamu mengadakan sekutu-sekutu bagi Allah. Kedua terjemah dari ayat di atas tidak menunjukkan 
adanya makna syarat. Akan tetapi jika dilihat dari kitab i'rab Mahmud Shafi, kalimat di atas mempunyai makna tersirat yang menyebabkannya menjadi sebuah kalimat syarat.

Kemudian pada surah Al-Baqarah ayat 23:

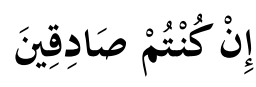

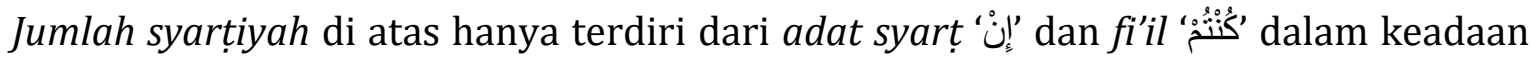
jazim menjadi fi'il syarț, sedangkan jawab syarț di-mahdzuf dan menunjukkan kepada makna kalimat sebelumnya. Hal ini sesuai dengan pendapat Ali Jazim dan Musțafa Amin

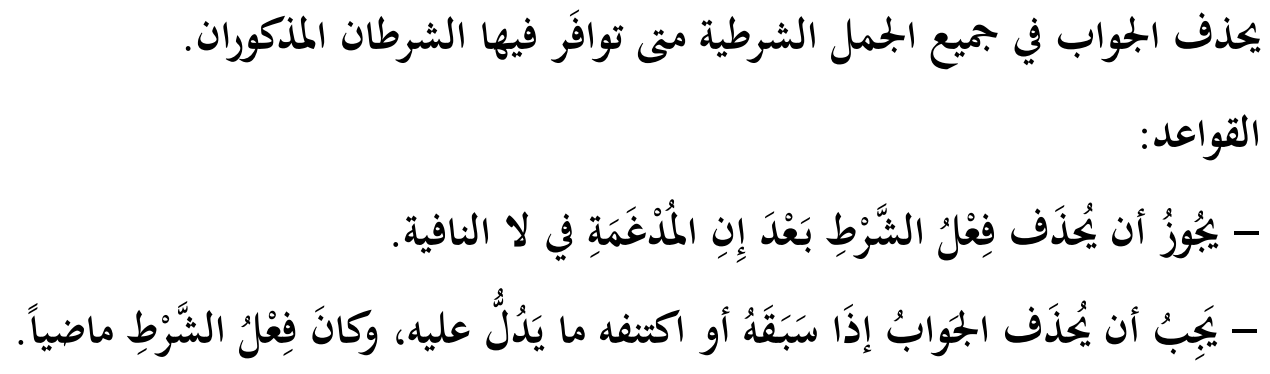

(Jarim, A \& Amin, tt:211).

Pada poin kedua, Jawab syarț pada jumlah syarțiyah di atas boleh di-mahdhuf karena telah ada makna yang menunjukkan jawab syart pada makna kalimat sebelumnya. Juga, fi'il syarț pada jumlah syarțiyah tersebut berupa fi'il māḍi.

Sedangkan terjemah dari jumlah syarțiyah di atas Jika kamu orang-orang yang benar hanya terdiri dari protasis tanpa adanya apodosis sebagai akibat dari protasis dan hanya ada Aka tanpa adanya predikat pada induk kalimat yang biasa dijelaskan oleh Aka. Adapun

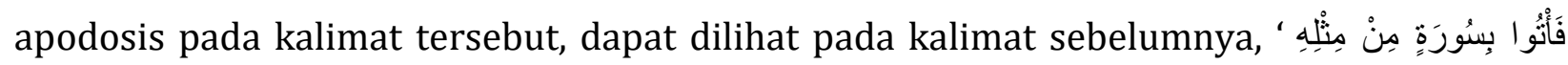
yang berarti maka buatlah satu surah semisal dengannya dan ajaklah penolong-penolongmu. Kalimat ini berperan sebagai apodosis untuk kalimat syarat di atas juga pada kalimat syarat sebelumnya, masih pada ayat yang sama.

Adapaun pada terjemah Al-Mishbah, kalimat di atas memiliki terjemah yang sama dengan terjemah Depag sehingga peneliti tidak membahasnya kembali.

Kemudian, pada ayat 31, ditemukan juga Jumlah syarțiyah yang sama. Akan tetapi, pada ayat ini, ditemukan sedikit perbedaan pada sisi penerjemahannya. Pada penerjemahan Depag, jumlah di atas diterjemahkan sebagai jika kamu yang benar, sedangkan pada terjemah Al-Mishbah diterjemahkan sebagai jika kamu 'orang-orang' yang benar.

4. Perbandingan Kalimat Syarat Bahasa Arab dan Bahasa Indonesia 
Setelah menganalisis struktur kalimat syarat bahasa Arab dan bahasa Indonesia, peneliti menemukan beberapa persamaan dan perbedaan kalimat syarat pada keduanya. Persamaan yang pertama, kalimat syarat baik dalam bahasa Arab maupun bahasa Indonesia, terdapat penyebab yang menjadikannya sebagai kalimat syarat. Pada bahasa Arab, kalimat syarat ditandai dengan adanya adawat syarț sedangkan pada bahasa Indonesia ditandai dengan adanya konjungsi yang menyatakan syarat.

Pada jumlah syarțiyah terdapat adawat syarț baik jazim ataupun ghair jazim. adawat

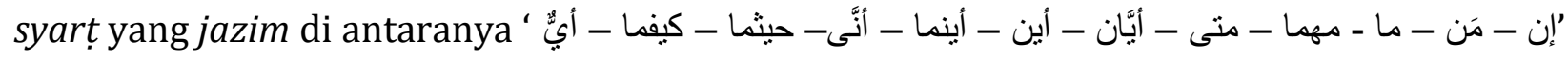
adapun adawat syarț yang ghair jazim di antaranya 'إذا ، لو لا ، لوما، كلما ، أما ، لما'.

Sedangkan dalam bahasa Indonesia ditandai dengan adanya konjungsi yang menyatakan syarat ataupun pengandaian di antaranya, kata-kata kalau, jika, jikalau, bila, bilamana, apabila, dan asal. Disamping itu ada pula persyaratan yang berupa pengandaian, yakni kata-kata andaikata, seandainya, dan andaikan.

Hubungan syarat terjadi dalam kalimat yang klausa subordinatnya menyatakan syarat terlaksananya apa yang disebut dalam klausa utama. Subordinator yang lazim dipakai adalah jika(lau), seandainya, andaikata, andaikan, dan asal(kan). Di samping itu, subordinator kalau, (apa)bila, bilamana juga dipakai jika syarat itu bertalian dengan waktu (Putrayasa, 2010:96). Hubungan pengandaian terdapat dalam kalimat majemuk yang klausa subordinatifnya menyatakan suatu tujuan atau harapan dari apa yang disebut dalam klausa utama. Subordinator yang lazim dipakai adalah seandainya, andaikata, andaikan, dan sekiranya (Putrayasa, 2010:97).

Kedua, kalimat syarat dalam bahasa Arab (jumlah syarțiyah) tesusun atas dua bagian, yaitu jumlah syarț dan jawab syarț. jumlah syarț berupa kalimat yang atau klausa yang menyatakan adanya syarat dan jawab syarț sebagai jawaban atau akibat dari pernyataan pada kalimat syarat.

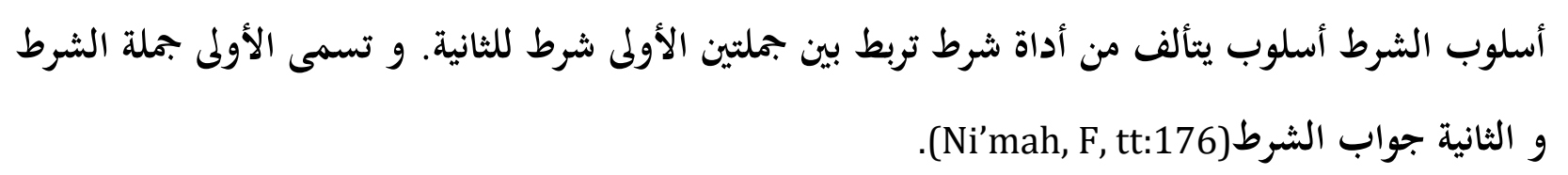

Dalam bahasa Indonesia, kalimat syarat juga terdiri dari dua bagian, yaitu protasis dan apodosis. Protasis adalah bagian klausa yang mengandung makna pesyaratan, sedangkan apodosis adalah bagian klausa yang menunjukkan akibat dari protasis. Kalimat 
persyaratan adalah kalimat bersusun yang mengandung protasis dan apodosis (Harimurti, 2001:94).

Berdasarkan keterangan sebelumnya, bisa disimpulkan bahwa jumlah syarț dalam bahasa Arab sama dengan protasis dalam bahasa Indonesia, sedangkan jawab syart dalam bahasa Arab sama dengan apodosis dalam bahasa Indonesia. Seperti pada ayat berikut:

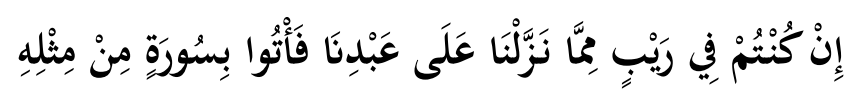

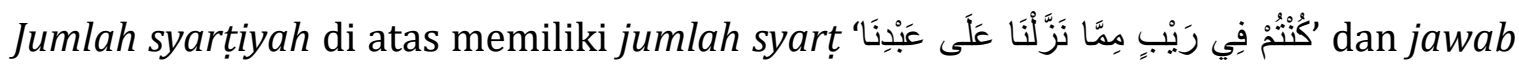

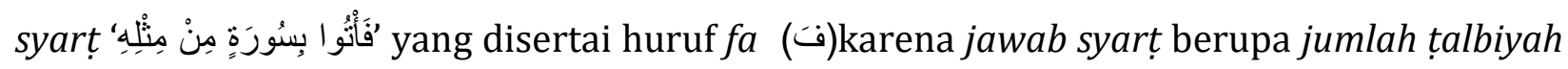
dengan bentuk fi'il amr.

Kemudian dalam kalimat bahasa Indonesia, Kalimat jika kamu meragukan (Al-Qur'an) yang kami turunkan kepada hamba kami (Muhammad) sebagai protasis di mana kalimat tersebut menyatakan keterangan syarat. Kemudian, kalimat maka buatlah satu surah semisal dengannya sebagai apodosis di mana kalimat tersebut menyatakan akibat dari kalimat syarat sebelumnya.

Adapun perbedaan pada kalimat syarat bahasa Arab dan bahasa indonesia di antaranya:

Pertama, dalam kalimat syarat bahasa Arab salah satu fi'il syarț ataupun jawab syart bisa di-mahdhuf, sehingga salah satu fi'il syarț ataupun jawab syarț dalam keadaan muqaddar atau menunjukkan kepada makna sebelum kalimat syarat tersebut. Sedangkan dalam Bahasa Indonesia, kalimat yang menyatakan syarat tidak ada, akan menimbulkan makna yang kurang tepat. Seperti pada surah Al-Baqarah ayat 40:

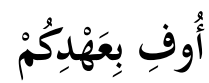

(أوف). لا محلّ لما جواب شرط مقدّر غير مقتزنة بالفاء أي: إن توفوا أوف(Shafi, M. 1990:113).

Pada jumlah syarțiyah di atas, hanya terdiri dari jawab syarț muqaddar dengan fi'il mudhari' majzum dan tidak disertai dengan harf ' 3 '.Pada ayat di atas, tidak ditemukan adanya adat dan fi'il syart. Namun, jumlah di atas disebut sebagai jawab syart muqaddar dengan adat dan fi'il syart yang tersirat.

Jika diterjemahkan dalam bahasa Indonesia menjadi Aku penuhi janji-Ku kepadamu. kalimat tersebut hanya terdiri dari kalimat sederhana yang terdiri dari subjek $A k u$, predikat penuhi, objek janji-Ku dan keterangan kepadamu. Tidak ada kata yang menunjukkan persyaratan. 
Kemudian pada surah Al-Baqarah ayat 23:

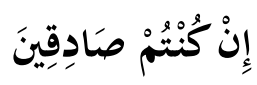

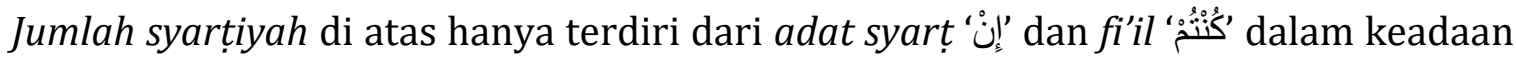
jazim menjadi fi'il syarț, sedangkan jawab syarț di-mahdzuf dan menunjukkan kepada makna kalimat sebelumnya. Hal ini sesuai dengan pendapat Ali Jazim dan Musțafa Amin

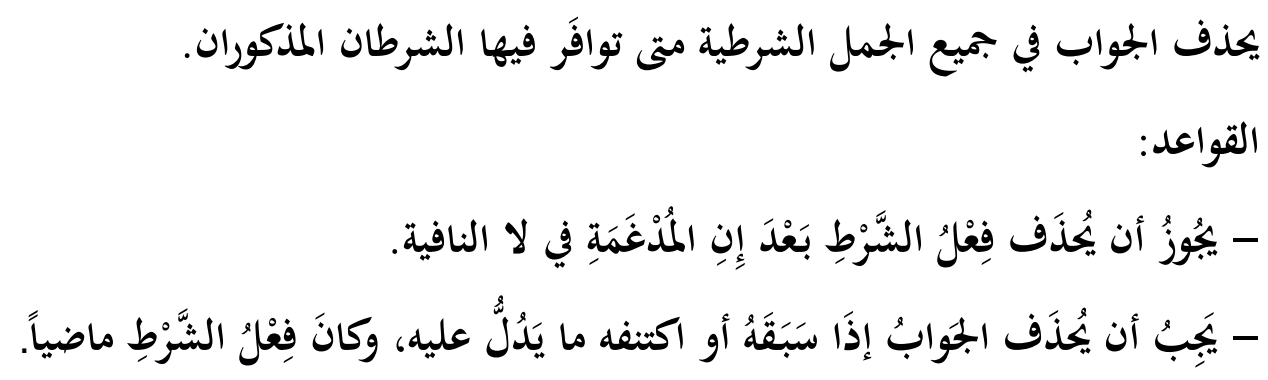

(Jarim, A \& Amin, $\mathrm{tt}: 211)$

Berdasarkan pada poin kedua, Jawab syarț pada jumlah syarțiyah di atas boleh dimahdhuf karena telah ada makna yang menunjukkan jawab syart pada makna kalimat sebelumnya. Jawab syarț untuk jumlah di atas menunjuk kepada makna di jumlah sebelumnya di ayat 23, namun jumlah tersebut tidak memiliki kedudukan sebagai jawab syarț dalam bahasa Arab. Karena jawab syarț dalam bahasa Arab terletak pada jumlah kedua dalam uslūb syarț.

Sedangkan dalam bahasa Indonesia, urutan pada kalimat persyaratan tidak terpaku pada urutan. Pada kalimat majemuk bertingkat, konjungsi pesyaratan yang umumnya terdapat pada Aka bisa disimpan pada klausa pertama ataupun klausa lainnya.

Kedua, beberapa adat syart dalam bahasa Arab jika terjemahkan ke dalam bahasa indonesia, tidak menjadi konjungsi yang menyatakan syarat. Seperti adat syarṭ " jika diterjemahkan ke dalam bahasa Indonesia diartikan sebagai adapun dan konjungsi adapun bukan termasuk dalam konjungsi syarat.

Ketiga, dalam bahasa Arab, urutan posisi fi'il syarț dan jawab syarț tidak dapat berubah atau ditukar, karena akan memiliki wazifah yang berbeda. Sedangkan dalam bahasa Indonesia, protasis sebagai kalimat yang menyatakan syarat yang ditandai dengan adanya konjungsi, bisa bertukar posisi dengan apodosis sebagai induk kalimat yang menyatakan akibat.

5.Implikasi Penelitian Terhadap Penerjemahan 
Pada bagian ini, peneliti akan memaparkan implikasi penelitian ini terhadap penerjemahan. Dilihat dari terjemah Depag maupun Al-Mishbah, penggunaan harf ' ${ }^{\prime}$ ' pada jawab syarț dalam jumlah syarțyah bahasa Arab, tidak semuanya mesti diterjemahkan ke dalam bahasa Indonesia. harf ' $\omega$ ' bisa berarti maka, niscaya, karena itu, sebab itu dan lain sebagainya atau tidak diterjemahkan sama sekali. Pada kalimat yang bersifat larangan atau perintah, harf ' $\omega$ ' biasa diartikan maka ataupun tidak diterjemahkan. Namun, terdapat bebeapa jawab syarț yang tidak disertai dengan harf" $\mathbf{\omega}^{\prime}$ namun pada penerjemahannya memakai kata seperti maka, niscaya, supaya dan sebagainya.

Seperti jumlah yang terdapat pada surah Al-Baqarah ayat 112:

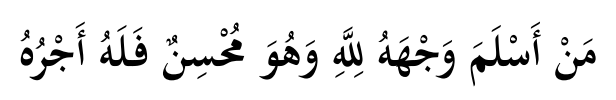

Dalam terjemah Depag diterjemahkan sebagai, Barang siapa menyerahkan diri sepenuhnya kepada Allah, dan dia bebuat baik, dia mendapat pahala di sisi Tuhannya. Sedangkan pada terjemah Al-Mishbah, Siapa yang menyerahkan wajahnya kepada Allah, sedang ia muhsin, maka baginya pahala dari sisi Tuhannya. Pada terjemah Depag, harf'ف' tidak diterjemahkan. ada terjemahan ini, penerjemah menggunakan teknik reduksi, di mana penerjemah memadatkan informasi teks bahasa sumber dalam bahasa target (Al Farisi, 2014:79).

Sedangkan pada terjemah Al-Mishbah, harf“' diterjemahkan sebagai maka. Pada terjemahan ini, penerjemah menggunakan teknik literal, di mana penerjemah mengalihkan langsung ungkapan teks sumber ke dalam teks target yang sepada secara gramatikal (Al Farisi, 2014:79). Dalam kamus Al-Munawwir, harf“' ${ }^{\prime}$ untuk 'ațf diterjemahkan sebagai kemudian, sedangkan harf'ف' untuk jawab syarț diterjemahkan sebagai maka.

Setiap jumlah syarțiyah memiliki makna sebab-akibat. Hanya saja, makna sebab dan akibat tersebut ada yang ternyatakan secara implisit (tidak ditandai dengan adanya penghubung) dan eksplisit (dinyatakan dengan adanya penghubung). Jawab syart mempunyai makna akibat. Namun, makna akibat pada Jawab syarț tidak semuanya ditandai dengan adanya penghubung yang menyatakan sebab. Seperti pada surah Al-Baqarah ayat 17, Jawab syart tidak ditandai dengan adanya penghubung yang menyatakan akibat, namun memiliki makna sebagai akibat dari jumlah sebelumnya. Sedangkan pada ayat 26, pernyataan akibat pada Jawab syart ditandai dengan adanya penghubung yang menyatakan akibat yaitu maka. 
Seperti jumlah syarțiyah pada ayat 246,

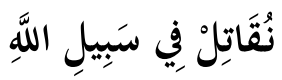

Pada terjemah Depag, jumlah tersebut diartikan sebagai Niscaya kami berperang di jalan Allah, adapun pada terjemah Al-Mishbah diartikan sebagai Supaya kami berperang di jalan Allah. Pada terjemahan Depag diberi terjemah niscaya, sedangkan pada terjemah AlMishbah diberi terjemah supaya.

Kemudian, dalam penelitian ini peneliti menemukan bahwa pada terjemahan Depag, adat syart 'إ' dalam surah Al-Baqarah hampir semuanya diterjemahkan sebagai jika, dalam KBBI diartikan sebagai kata penghubung yang dipergunakan untuk menandai syarat (janji); dan menurut Chaer (2009), konjungsi jika juga bisa digunakan untuk menggantikan konjungsi kalau. Akan tetapi, pada ayat 233 adat ini diterjemahkan sebagai apabila yang dalam KBBI disebutkan bahwa kata tersebut bisa berarti jika atau kalau.

Begitu pula pada terjemah Al-Mishbah, adat syarț 'ب!' seringkali diterjemahkan sebagai jika seperti pada ayat 23, 24, 31, 85, 91, 93, 94, 111, 120 dan ayat lainnya. Namun, beberapa adat syarț 'إن' diterjemahkan sebagai seandainya yang menurut KBBI bisa diartikan sebagai seumpama; andai kata; andaikan, seperti pada ayat 209, 211, 230. Dan sama seperti pada terjemah Depag, adat syart 'إن' pada ayat 223 diterjemahkan sebagai apabila.

Sedangkan adat syarț 'إذا' pada surah Al-Baqarah dalam terjemah Depag selalu diterjemahkan sebagai apabila, kecuali pada ayat 233 adat syarț 'إذإ' diterjemahkan sebagai jika. Begitu pula pada terjemah Al-Mishbah, adat syarț ' إذا selalu diterjemahkan sebagai apabila, namun adat syarț ' إذإl pada ayat 11, 14, 20 dan 117 diterjemahkan sebagai bila. Konjungsi bila digunakan untuk menghubungkan menyatakan 'syarat' dapat digunakan untuk menggantikan konjungsi kalau (Chaer, 2009).

Kemudian adat syart 'من' pada terjemah Depag sering diterjemahkan sebagai barang siapa seperti yang tertulis di ayat 38, 81, 97, 98, 108 dan lainnnya. Dalam KBBI, barang siapa diartikan sebagai siapa saja. Begitu pula pada terjemah Al-Mishbah sering kali diterjemahkan sebagai barang siapa, tetapi pada ayat 112 dan 249 penerjemah menerjemahkannya sebagai siapa.

Akan tetapi, pada ayat 196, adat syarț 'من 'tidak diterjemahkan sebagai siapa ataupun barangsiapa. 


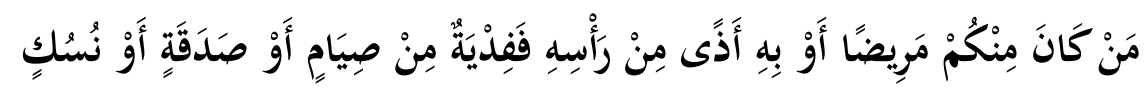

Pada terjemah Depag diterjemahkan menjadi, Jika ada di antara kamu yang sakit atau ada gangguan di kepalanya (lalu ia bercukur), maka wajiblah atasnya berfidyah, yaitu berpuasa atau bersedekah atau berkurban. Adapun terjemah dari Al-Mishbah, Jika ada di antara kamu yang sakit atau ada gangguan di kepalanya (lalu dia bercukur), maka dia wajib berfidyah, yaitu berpuasa, bersedekah, atau berkurban. Setelah peneliti amati, adat syarț 'من' pada kedua terjemah tersebut, baik Depag maupun Al-Mishbah menerjemahkannya sebagai jika.

Adapun untuk adat syart ' لو', memiliki penerjemahan yang sangat beragam, baik dalam terjemah Depag ataupun terjemah Al-Mishbah. Dalam terjemah Depag, pada ayat 8, 102, dan 103 adat syart ' لو diterjemahkan sebagai sekiranya, pada ayat 103 dan 220 diterjemahkan sebagai jika, pada ayat 165 dan 167 diterjemahkan sebagai seandainya, pada ayat 170 diterjemahkan sebagai walaupun, pada ayat 221 diterjemahkan sebagai meskipun, dan pada ayat 253 diterjemahkan sebagai kalau.

Pada terjemah Al-Mishbah, ayat 8 adat syart ' لو' diterjemahkan sebagai jikalau, pada ayat 102 dan 103 diterjemahkan sebagai kalau, pada ayat 103 dan 253 diterjemahkan sebagai seandainya, pada ayat 170 dan 221 diterjemahkan sebagai walaupun, dan pada ayat 220 diterjemahkan sebagai jika.

Kemudian untuk adat syart ' لو ' Depag diterjemahkan sebagai sekiranya bukan, dan pada ayat 251 diterjemahkan sebagai kalau tidak. Sedangkan pada terjemah Al-Mishbah, adat syart ' 'لو' pada ayat 64 diterjemahkan sebagai kalau tidak dan pada ayat 251 diterjemahkan sebagai seandainya tidak.

Selanjutnya, untuk adat syarț ' لّّ' pada surah Al-Baqarah ayat 17, 33, 89 dan 101 baik pada terjemah Depag ataupun Al-Mishbah menerjemahkannya sebagai setelah. Sedangkan pada ayat 249, 250, dan 259, terjemah Depag menerjemahkannya sebagai ketika dan AlMishbah menerjemahkannya sebagai tatkala. Kemudian, untuk adat syarț ' كلّما pada surah Al-Baqarah ayat 20 dan 100 baik pada terjemah Depag ataupun Al-Mishbah menerjemahkannya sebagai setiap kali. Sedangkan pada ayat 87 keduanya menerjemahkannya sebagai setiap. 
Selanjutnya, untuk adat syart ‘ 'مّأ pada surah Al-Baqarah ayat 20 baik pada terjemah Depag ataupun Al-Mishbah menerjemahkannya sebagai adapun. Kemudian, adat 'ما' pada surah Al-Baqarah ayat 110, 197, 215, 270, 272 dan 273 terjemah Depag ataupun Al-Mishbah mempunyai makna maushul. Tetapi, pada ayat 106 terjemah Al-Mishbah, adat tersebut mempunyai makna nafiah.

Adapun adat syarț lain yang peneliti temukan adalah حيثما أينما. Baik pada terjemah Depag maupun Al-Mishbah adat أينما pada ayat 148, diterjemahkan sebagai di mana saja. Begitupun dengan adat حيثم Lpada ayat 144 dan 150 diterjemahkan sebagai di mana saja pada terjemah Depag dan Al-Mishbah.

\section{SIMPULAN}

Persamaan pada jumlah syarțiyah dan kalimat syarat dalam bahasa Indonesia di antaranya, terdapat adat syart dan konjungsi yang menyebabkan kalimat syarat. Kemudian, jika dalam jumlah syarțiyah terdapat fi'il syarț dan jawab syarț, maka dalam kalimat syarat bahasa Indonesia terdapat kalimat protasis dan apodosis. Adapun perbedaannya, salah satu unsur pada pada jumlah syarțiyah dapat dimahdhuf sedangkan dalam bahasa Indonesia tidak bisa karena akan membuat kalimat memiliki makna yang berbeda. Kemudian, tidak semua adat syarț jika diterjemahkan akan menjadi konjungsi yang menyatakan syarat. Dan terakhir, posisi pada fi'il syarț dan jawab syarț pada bahasa Arab tidak dapat ditukar, sedangkan dalam bahasa Indonesia dapat ditukar.

Adapun implikasi penelitian ini terhadap penerjemahan adalah bahwa tidak semua harf 'ف diterjemahkan ke dalam bahasa Indonesia. Juga, terjemah harf" $\mathbf{}$ ' bisa berbeda-beda maknanya tergantung konteks kalimat yang dipakai. Kemudian penerjemahan konjungsi syarat menjadi adat syarț hendaknya memerhatikan konteks kalimat, sehingga bisa menentukan adat syart yang sesuai. Sebab dalam bahasa Indonesia, suatu konjungsi syarat dapat menggantikan fungsi konjungsi syarat lainnya. Sehingga penerjemahan satu adat syart bisa berbeda-beda antara satu ayat dengan ayat lainnya.

\section{DAFTAR PUSTAKA}

Ahmadi. (2014). “Analisis Kontrastif dan Analisis Kesalahan dalam Pembelajaran Bahasa Arab sebagai Second Language". Jurnal Ilmu Tarbiyah "At-Tajdid". 3(1): 123-152.

Al Farisi. (2014). Pedoman Penerjemahan Arab Indonesia. Bandung: Remaja Rosdakarya. Ar-Rajih, A (2000). At-Tatbiq al-Nahwi. Al-Iskandariyah: Dar al-Ma'rifah al-Jami'iyah. 
Bihauddin, 'Ali. (1987). Al-Madkhal al-Nahwi.

Chaer, A. (2007). Tata Bahasa Praktis Bahasa Indonesia. Jakarta: Rineka Cipta.

Chaer, A. (2009). Sintaksis Bahasa Indonesia (Pendekatan Proses). Jakarta: PT Rineka Cipta.

Departemen Agama RI. (2015). Al-Quran Terjemahan Bandung: CV Darus Sunnah.

Harimurti. (2001). Kamus Linguistik. Jakarta: PT Gramedia Pustaka Utama.

Jarim, A \& Amin, M. (t.t.). An-Nahwu al-Wadih fi qawa'id al-Lugah al-Arabiyah.Maktabah Syamilah.

Kridalaksana, H. (2001). Kamus Linguistik. Jakarta: PT Gramedia Pustaka Utama.

Ni'mah, F. (t.t.). Mulakhas Qawaid al-Lugah al-'Arabiyah.

Putrayasa, I. B. (2010). Analisis Kalimat (Fungsi, Kategori dan Peran). Cet. 3. Bandung: PT Refika Aditama.

Shafi, Mahmud. (1990). Al-Jadwal fi i'rabi al-Qur'an wa sarfihi wa bayanihi. Bairut: Dar Arrasyid.

Shihab, Muhammad Quraish. (2001). Tafsir Al-Misbah: Pesan, Kesan dan Keserasian alQur'an.Jakarta: Lentera.

Suhendar, U. (2014). Dasar-Dasar Ilmu Nahwu dan Sharaf untuk Memahami Gramatika AlQur'an dan Hadits. Tasikmalaya: Al-Razi. 